\title{
An Interpretation of the Play After the Fall Based on Role- and -Value Cognitive Concept*
}

\author{
Ying Fang \\ College of International Studies, Yangzhou University, Yangzhou, Jiangsu, China
}

\begin{abstract}
The paper aims to interpret Arthur Miller's stream-of-consciousness play text, After the Fall, from the perspective of the cognitive concept of evolving reference, namely "role and values". The results of the study are as follows: 1 . Mutual across-time-and-space contextual embedment or entanglement is the distinctive feature of stream-of-consciousness play text, which makes it possible to present synchronically what has happened diachronically, so that the various values generated by role switching over the past years are accessible in a while. 2. This feature in turn makes characterization more natural, true-to-life, vivid and substantial, revealing not only the different aspects of the protagonist's disposition but also the shaping process involved. 3. Despite the seemingly disordered contextual entanglement, the values through role switching are implicitly linked by the cause-effect logical relationship, which ensures the textual coherence of the play.
\end{abstract}

Index Terms - characterization, coherence, stream-of-consciousness plays, evolving reference, role and values

\section{INTRODUCTION}

In literary criticism, stream of consciousness is a narrative mode that attempts "to depict the multitudinous thoughts and feelings which pass through the mind of a narrator" (Cuddon, 1984). In novels, a character expresses their own interior memories, desires, speculations, obligations or other forms of non-real situations in their reported direct thoughts, free indirect thoughts, or narrator's presentation of thought act (Leech and Short, 2007). But in plays, characters' thoughts are presented mostly in dialogues and monologues.

Arthur Miller's play After the Fall presents what keeps happening in the mind, thought and memory of the main character, Quentin. As Marino (2005) observes, "Miller returned to the Expressionistic technique he had used in Death of a Salesman by setting the entire play, as he indicated in the staging notes, 'in the mind, thought, and memory' of the main character". As readers, we need to keep track of the different states of mind of characters, and observe which text world level they are attached to (Stockwell, 2014).

\section{LITERATURE REVIEW OF ROLE AND VALUES}

\section{A. Dichotomy of Role and Values}

In Fauconnier's account of categorization, noun phrases, rather than simply identifying people, things or concepts, are seen as performing roles or role functions. Thus, 'definite descriptions are primarily role functions and secondarily the value taken by such roles. The domain of the role may include times, places, situations, contexts and much more' (Fauconnier, 1985). Statements, such as "The president changes every seven years", "Your car is always different", "Your apartment keeps getting bigger and bigger", 'The president', 'your car', and 'your apartment', do not have one fixed referent in reality. Thus Fauconnier, in describing noun phrases, says that they can have 'a fixed identity, but their other properties can change' (1985). The linguistic elements of a mental space may identify a role or its role value. An element may either be understood as pointing to an abstract concept, a role, or it may be understood as pointing to a particular individual, a value.

Nunberg (1978) holds that the link between a role and its value for some setting of parameters is itself a pragmatic function. Proper names also have role interpretations under suitable pragmatic conditions. The changing contexts highlight the functional value of a definite description and the multiple values at hand. From this point of view, a description, as role, will change values from one space to another. This accounts easily for the phenomena discussed by Kripke (1979), that is, the scope of a description depends on which space the element described belongs to. In other words, the interpretation of values of proper names has more to do with social contexts or literary narrative structures.

Lakoff (1993) regards variations of roles in fiction as "multiple selves" or Dualistic Person or the dichotomy of "subject" and "the self". Emmott (1992), Gavins (2007) and Stockwell (2014) define it as "enactor". For example, there are different enactors of "Pip" in Great Expectations. When Pip was small, he was humble, kind, and loving. These traits are mainly attributed to his impoverished childhood. But Pip gradually changes to a bitter and snobbish person after he meets Magwich, his benefactor but a convict. Having gone through dramatic ups and downs, Pip finally

\footnotetext{
* This study is funded by a research grant for "A Study of Chinese and Western Dramas in the 20th Century" from Jiangsu Education Department, China (ref. 2021SJA1970).
} 
resumes his loving and kind nature. There also exist two distinct versions of Dorian Gray in Oscar Wilde's The Portrait of Dorian Gray: one for "reality" and the other for the "picture". Dorian Gray remains youthful, while the painting of him becomes old and horrid. Dorian is so appalled by his changing image in the painting that he resorts to hiding it in the attic. Later when the painting is changed into a splendid portrait, Dorian Gray is found lying on the floor in evening dress, with a knife in his heart. "He was withered, wrinkled, and loathsome of visage. It was not till they had examined the rings that they recognized who it was".

The split versions of the protagonists also appear in plays. In Miller's early play Death of a Salesman, the protagonist Willy Loman appears to be a very active, passionate, confident, hopeful man in his flashbacks or fantasy worlds, whereas in the text actual worlds which are based on the last 24 hours of his life, he is irritable, pessimistic, grumbling and desperate. The different versions of Willy Loman, which exist at different conceptual levels of a discourse, give readers an overall view of his personalities, which are found to be in conflict with the social and cultural value orientation of his times (Fang, 2013). That is why understanding a rounded character requires readers to integrate different piecemeal values of the same character at different stages of their lives or in different circumstances.

\section{B. Role/Value identification in After the Fall}

Quentin's mental journey involves ascending, descending and horizontal metaleptic jumps. Such three types of unnatural metalepses were put forward by Bell and Alber (2012). According to them, in an ascending metalepsis a fictional character or narrator jumps from an embedded story world to a hierarchically higher one, whereas in a descending metalepsis, a narrator or a character jumps into an embedded story world or an author jumps from the actual world into a story world. In addition to these two vertical types of metalepsis, there are horizontal metalepsis that represent transmigrations between story worlds (Bell \& Alice 2012). Quentin's vertical jumps include interactions either between the text actual world and the story world where he interacts with Holga or between Holga's story world and the embedded story worlds about his past relationships. His horizontal transmigrations refer to his interactions with his two ex-wives, Louise and Maggie, his mom Rose and brother Dan, his friend Lou together with Lou's wife Elise. The diagram of his stream-of-consciousness is depicted as follows:

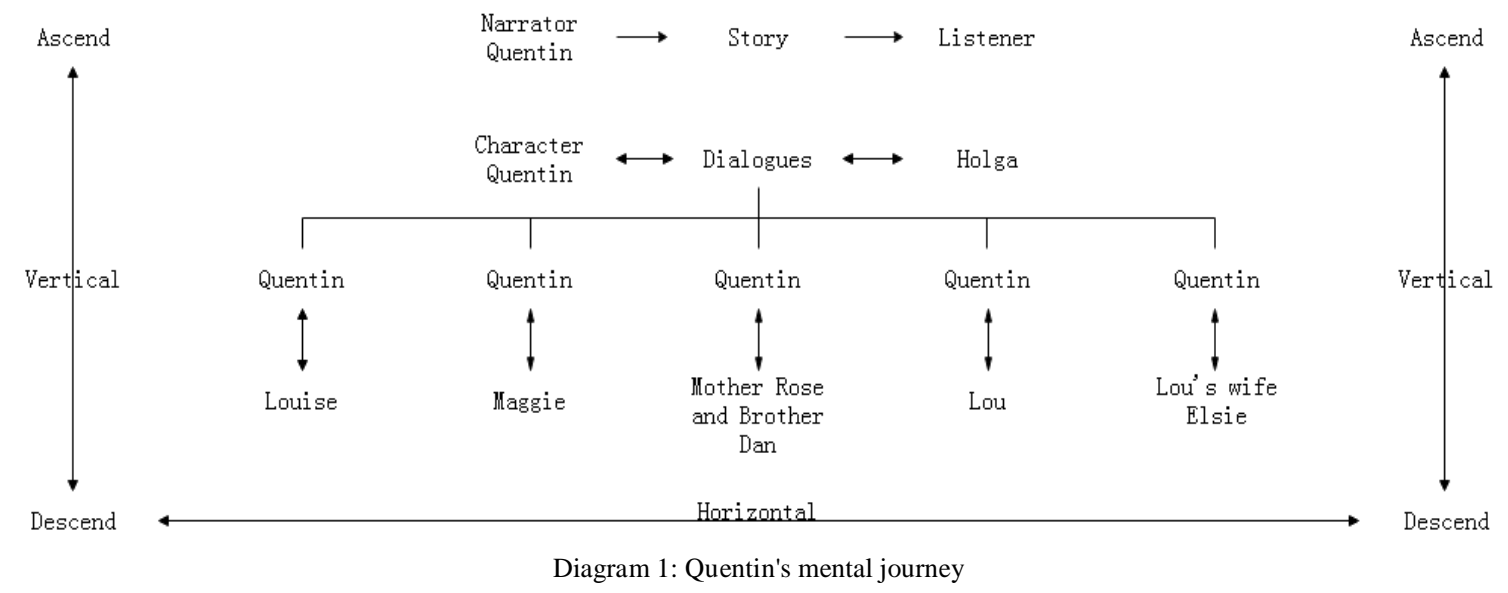

The interwoven texture contributes to characterization of multi-faceted characters. Among vertical metaleptic jumps, the Role of Quentin demonstrates different values at different layers. According to Fauconnier's definition, the distinction of Role and Values should be closely related to their pragmatic implication. Every time the stage direction "to the Listener" appears, it signals Quentin's anchor is ascending to the text actual world, in which Quentin expresses his uncertainty and hesitation about starting a new romantic relationship with Holga, a German archaeologist. So I mark the value in the text actual world as Quentin ${ }^{1}$. On the surface, Quentin is addressing the Listener whom he does not indicate the exact identity, but the stylistic feature of his speeches to "the Listener" is more like a monologue full of introspection and self-blaming. Quentin's interaction with Holga is viewed as Quentin ${ }^{2}$, because Holga's unique life experience brings a new perspective for his life. She was a member of the resistance organization during World War II and was not betrayed by her comrades even though they were arrested and executed. She survived and chose archaeology as her career. She took Quentin to the Concentration Camp and discussed the meaning of life with him. Her remark that it is a mistake to look for hope outside one's self makes Quentin feel so refreshed and encouraged. However, looking back upon his unhappy life in the past, especially his two failed marriages and his betrayal of his best friend Lou, Quentin is hesitant about committing himself again. When Quentin keeps recollecting the old days, transmigrating between different story worlds, interacting with his ex-wives, his lovers, his family members, etc., he is marked as Quentin'.

\section{SynChronic PRESENTATION OF What HAPPENED DiACHRONICALly}

The benefit of the analysis based on role- and -value dichotomy is that it enables what happened diachronically to be 
presented synchronically, so that the various values generated by role switching over the past years are clear or accessible all at once. The following excerpt covers a long period, including Quentin's metaleptic jumps across three vertical levels, involving "Quentin"1", "Quentin" and "Quentin".

Quentin ${ }^{2}$, as though drawing on his courage, suddenly turning to her: Holga. I thought I noticed your pillow was wet this morning.

Holga: It really isn't anything important.

Quentin $^{2}$ : There are no unimportant tears.

Holga: I feel sometimes-Breaks off, then: - that I'm boring you.

Louise, entering upstage: I am not all this uninteresting, Quentin ${ }^{3}$ !

He stares at her, trying to join this with his lost vision, and in that mood he turns out to the Listener.

Quentin ${ }^{1}$ : The question is power, but I've lost the ...Yes!

$\mathrm{He}^{3}$ springs up and circles Louise.

...

Holga: I may not be all that interesting. I wish you'd believe me, Quentin; you have no duty here.

Quentin $^{2}$ : Holga, I would go. But I know I'd be looking for you tomorrow.

Mother enters, taking Holga's place on the seat beside him.

Quentin ${ }^{1}$ continues speaking without pause. But there's truth in what you feel. The time does come when I feel

I must go. Not toward anything, or away from you... But there is some freedom in the going.

As could be seen from the above, Quentin accidentally noticed that Holga was upset by his ever-weakening affection for her. Holga's remark "I feel sometimes I'm boring you" reminds him of his first ex-wife Louise's similar complaint "I'm not all this uninteresting!" His monologue-like stream of consciousness, that is, "The question is power, but I've lost the...Yes!" suggests that his true face is seen through by people and that he no longer has enough power to manipulate his women, who all have independent thoughts of their own. The stage direction "Mother enters..." seems to reveal that his deceased mother's negative influence on him still exists. What Quentin ${ }^{1}$ says reveals his sense of helplessness and introspection about what he has done. All such happenings cover three time-space domains, involving various characters, but are effectively presented all at once, successfully creating a rounded Quentin with vivid details.

\section{Multi-Dimensional DisPlay of Quentin's Personalities}

The values generated by role-switching, as seen in the above, make characterization more natural, true-to-life, vivid and substantial, revealing not only the different aspects of the protagonist's personalities but also the shaping process involved. Quentin's mental horizontal transmigration enables readers to gain a glimpse of his failed marital relationship in the past. Quentin's second ex-wife Maggie catches him having an affair with his best friend, Lou's wife, Elise. However, Quentin does not feel ashamed of it because this is his habitual behavior. His first ex-wife, Louise, makes similar complaints about his infidelity "You've been trying to keep the home fires burning and see the world at the same time", "You must know how I felt when I found that letter in your suit". It seems that Quentin takes fickleness in marital life for granted. He keeps abandoning the old and seeking the new. Both Louise and Maggie complain about Quentin's coldness and indifference, as Louise says "we don't seem...married.... You don't pay any attention to me..." (p.282), and then she reproaches his misunderstanding of women, including a misconception about herself, "You have no conception of what a woman is... You think reading a brief to a woman is talking to her? What do you need a wife for? What am I to you?" (p.283). All this testifies to Quentin's domestic emotional violence, his ignorance about the responsibility in marriage and his lack of respect for women's rights and dignities.

Quentin treats Maggie quite differently before and after the marriage. In the following excerpt, when they first meet, Quentin gives Maggie empty promises as his brother Dan used to do to him:

Maggie: And---what's moral, again.

Quentin $^{3}$ : To live the truth.

Maggie: That's you.

Quentin $^{3}$ : Not yet, dear; but I intend to try. Don't be afraid to call me if you need any help. She is suddenly gone. Alone, he continues the thought. Any time--Dan appears in crew-necked sweater with his book--you need anything, you call, y'hear?

DAN: This family's behind you, Quentin. Backing into darkness, with a wave of farewell as train whistle sounds: Any time you need anything ...

Quentin ${ }^{1}$ surprised, he has turned quickly to Dan, who disappears; and to the Listener, as he still stares at the empty space Dan has left: You know? It isn't fraud, but some...disguise. I came to her like Dan--his goodness! No wonder I can't find myself!

The above is the juxtaposition of Quentin ${ }^{3}$ who is addressing Maggie before their marriage and Quentin ${ }^{1}$ who repents his immoral behavior and admitted being like his dishonest brother Dan. As Quentin reflects later, when Maggie took an overdose of drugs and attempted committing suicide after their marriage, he totally lost patience, sent her to the Institution and dissociated himself from her. That is why he labels himself above as a "disguise" or a liar.

The appearance of "Dan" is not accidental because it suggests the cheatings of Quentin by his brother Dan and his mother has a bad influence on the shaping of Quentin's disposition. 
Quentin's biggest regret in life is his attitude toward his best friend and colleague, Lou. Lou is a socialist, who is then tipped off by his colleague, Mickey, during the McCarthyism in the 1950s. Quentin has promised to defend him, but later on at the last minute Quentin changes his mind for fear of losing the job. The following is the dialogue between Louise and Quentin on the night when Lou dies. He knows better than anybody else that Lou's death is caused by despair.

Louise: What is it?

Quentin ${ }^{3}$ : Lou. Was killed by a subway train tonight.

Louise gasps: How?

Quentin ${ }^{3}$ : They don't know. They say "fell or jumped."

Louise: He couldn't have! The crowd must have pushed him!

Quentin $^{3}$ : There is no crowd at eight o'clock. It was eight o'clock.

Louise: But why? Lou knew himself! He knew where he stood! It's impossible!

Quentin ${ }^{3}$, staring: Maybe it's not enough--to know yourself. Or maybe it's too much. I think he did it.

Louise: But why? It's inconceivable!

Quentin $^{3}$ : When I saw him last week he said a dreadful thing. I tried not to hear it. Pause. She waits. That I turned out to be the only friend he had.

Louise, genuinely: Why is that dreadful?

Quentin $^{3}$, evasively, almost slyly: It just was. I don't know why. Tears forming in his eyes, Quentin ${ }^{l}$ comes toward Listener. I didn't dare know why! But I dare now. It was dreadful because I was not his friend either, and he knew it. I'd have stuck it to the end but I hated the Danger in it for myself, and he saw through my faithfulness; and he was not telling me what a friend I was, he was praying I would be - "Please be my friend, Quentin" is what he was saying to me, "I am drowning, throw me a rope!" ... I felt now that my Danger had spilled out on the subway track! So it is not bizarre to me.

The dialogue is between Louise and Quentin ${ }^{3}$. Apparently, Quentin understands the reason for Lou's suicidal better than Louise. In his introspection signaled by "Quentin ${ }^{1}$ comes toward Listener", he confesses he is afraid of the danger involved in Lou's case. If he had defended on Lou's part, he would have put himself in the danger of losing the job. By saying "I hated the Danger in it for myself", "I felt now that my Danger had spilled out on the subway track!", Quentin expresses his regret about failing to keep his promise to speak for his friend in the law court at the critical moment, which results in Lou's death.

Therefore, the above value through role-switching offers a multi-dimensional display of Quentin's personalities. Therefore, we have an overall picture of what Quentin is basically like. He is a man, who is negatively influenced by his family members and his domestic atmosphere, which in turn affects the shaping of his personalities. He is a man, who is unfaithful in marital life, almost addicted in abandoning the old and seeking the new. He is a man, who repeatedly exercises domestic emotional violence and pay little attention to women's dignities and his marital responsibility. Also, he is a man, who finally finds himself disoriented in life and is beginning to repent, feeling the prick of conscience for what he has done.

\section{EXTERNAL DisORDER VS INTERNAL LOGIC RELATIONSHIP}

Despite the seemingly disordered contextual entanglement, the values of role switching are logically linked by the implicit cause-effect relationship, which ensures the textual coherence of the play text. The marginalization and the unhealthy domestic atmosphere experienced by Quentin in his childhood partly contribute to Quentin's selfishness in his later life and to his cold-hearted refusal to help his friend. His failed interpersonal relationship has a lot to do with his mother's treacherousness he witnessed in his childhood. As Moss (1980:58) observes, "Quentin's disorientation had its roots in his youth: two memories, both of which show his Mother to be treacherous".

His mother repeatedly reproached her frustrated husband when he lost money in the stock market crash. Instead of giving consolation, she became more aggressive and overbearing, criticizing his inability in business. In Quentin's memory, mother always spoke in a domineering or bossy tone:

"What are you winding up?",

"When did this start?",

"How much are you taking out of it?",

"You lost your mind?",

"You sold those wonderful stocks?",

"You mean you saw everything going down and you throw good money after bad?"

"Are you some kind of a moron?".

"You'd better cash your insurance",

"Do it tomorrow!", and

"You get them back!".

Flying into hysteria, she even regretted marrying him,

"I should have run the day I met you",

"I should have done what my sisters did, tell my parents to go to hell and thought of myself for once", 
"I should have run for my life! I ought to get a divorce!"

All such complaints of hers leave a very negative impression on Quentin. What makes Quentin intolerable is that she refused to admit any of her wrongdoings "What I said? Well, I was a little angry, that's all, but I never said that. I think he's a wonderful man! How could I say a thing like that? Quentin! I didn't say anything!" Unluckily, Quentin seems to be surrounded by such domineering women in her life. Lou used to be afraid of his wife Elsie. Whenever Elsie told off Lou in the presence of Quentin, Quentin involuntarily thought of the way his mom used to scold his father.

Lou, with a difficult grin and chuckle: Well, dear, I'm not all that delicate, I-

Elsie, with a sudden flash of contempt, to Lou: This is hardly the time for illusions!

Mother: You idiot! Quentin3 is shocked, turns quickly to Mother, who stands accusingly over the seated Father.

My bonds?

Quentin1: Why do I think of things falling apart? Were they ever whole?

The reason why his mother's words "You idiot" suddenly occurs to Quentin is that his mother often reproaches his father like this. Besides being dominant in the family, Quentin's mother badly hurt him by lying to him in order not to take him for traveling. One day she went off on a vacation without telling Quentin, "they sent me for a walk with the maid. When I came back the house was empty, which made me feel abandoned" (p.325). And the reason for Mother's deception is that she wanted a rest. Lack of trust in his childhood affects his later relationship with Lou. In the following excerpt, his friend Lou is tipped off by Mickey and is disillusioned by Quentin. Lou has no choice but to mount the subway platform to end his life.

Quentin1, his arms down, crying out to Listener: But in whose name do you turn your back?

Mickey: That we go together, Lou, and name the names! Lou!

Lou, staring at Quentin3, mounts the platform where the men wait for a subway train.

Quentin1: I saw it clear-in whose name you turn your back! I saw it once, I saw the name!

The approaching sound of a subway train is heard, and Lou leaps; the racking squeal of brakes.

Lou: Quentin! Quentin!

All the men look at Quentin3, then at the "tracks." The men groan. Quentin's hands are a vise against his head. The tower lights as ...

Mother enters in prewar costume, sailboat in hand, bending toward the "bathroom door" as before.

Quentin1: In whose name? In whose blood-covered name do you look into a face you loved, and say, now you have been found wanting, and now in your extremity you die! It had a name, it ...

Mother, toward the bathroom door: Quentin3? Quentin3?

Quentin3: Hah? He hurries toward her, but in fear.

Mother: See what we brought you from Atlantic City! From the boardwalk!

Men exit from subway platform. A tremendous crash of surf spins Quentin about, and Mother is gone and the light of the moon is rising on the pier.

As shown above, Quentin ${ }^{1}$ appears three times with the similar exclamation "in whose name do you turn your back", which could be regarded as his self-blaming. Mother's image also appears three times. She has just returned from her trip to Atlanta and tried to please Quentin with toys, but Quentin no longer trusts her because he was badly hurt. Lou's death and Mother's deception seemingly has no direct relations with each other, but an overview of the play text will reveal the implicit cause-and-effect relationship between them, that is, the lack of sincerity and mutual support Quentin witnessed in his childhood contribute to his selfishness and ego-centeredness in his later life. No wonder he finally refuses to help his friend at the last minute.

\section{CONCLUSION}

The stage direction "To the Listener" marks the ascending metalepsis of the play in which Quentin switches or jumps, as it were, from an embedded story world into a hierarchically higher one, whereas in a descending metalepsis, he jumps into an embedded story world. In addition to these jumps from the text actual world into the story world, Quentin travels or transmigrates between different story worlds. The dynamic feature of such stream-of-consciousness plays requires readers to keep track of the route markings in the maze of the play plot. In fiction, this could be achieved by observing the shifts of point of view, which are grammatically realized by tenses, moods, personal pronouns, space builders, and other cognitive operators. In plays, role-and-value distinction can be made by deictic shifts in stage directions like "to the Listener", "to Holga" and "Mother/Louise/Maggie appears", or the speaking tone. Some speak in a condescending and patronizing tone, while others speak in a relatively gentle way. Therefore, a knowledge of such linguistic forms helps readers to follow the dynamic feature of such play texts and enables them to tell apart role and values so that they could effectively catch the different values of the same role from the entanglement of complex temporal-spatial domains or story worlds.

\section{REFERENCES}

[1] Bell, A. \& Alber, J. (2012). Ontological Metalepsis and Unnatural Narratology. Journal of Narrative Theory, 42(2): 166-192. Retrieved January 3, 2021, from https://www.jstor.org/stable/24484758.

[2] Cuddon, J. A. (1984). A Dictionary of Literary Terms. Harmondsworth, Penguin Books. 
[3] Dam-Jensen, H. (2006). An Application of the Role-Value Distinction in Mental Space Theory to the Analysis of Definite and Indefinite Noun Phrases. Tidsskrift for Sprogforskning, 4(1), 245-273. https://doi.org/10.7146/tfs.v4i1.323.

[4] Emmott, C. (1992). Splitting the Referent: An Introduction to Narrative Enactors. In Davies, M. and Ravelli, L. (Eds.), Advances in Systemic Linguistics: Recent Theory and Practice (pp. 221-228). Pinter Publishers.

[5] Emmott, C. (1997). Narrative Comprehension: A Discourse Perspective. Oxford: Oxford University Press.

[6] Emmott, C. (2002). 'Split-selves' in fiction and in medical 'life-stories': Cognitive linguistic theory and narrative practice. In Semino, E, Culpeper, J (Eds.), Cognitive Stylistics: Language and Cognition in Text Analysis (pp. 153-182). Amsterdam: John Benjamins.

[7] Fang, Y. (2013). Adaptability of Discourse to Context as Perceived from Stage Directions-A Case Study of Death of a Salesman. Journal of Hohai University (Philosophy and Social Sciences), 15 (3), 86-89.

[8] Fauconnier, G. (1985). Mental Spaces: Aspects of Meaning Construction in Natural Language. Cambridge University Press.

[9] Gavins, J. (2007). Text World Theory: An Introduction. Edinburgh: Edinburgh University Press.

[10] Kripke, S. (1979). Speaker's Reference and Semantic Reference. In Peter A. French, Theodore E. Uehling. Jr and Howard K. Wettstein (Eds.), Contemporary Perspectives in the Philosophy of Language (pp. 255-296). University of Minnesota Press.

[11] Lakoff, G. (1993). The internal structure of the Self. In U. Neisser \& D. A. Jopling (Eds.), The Conceptual Self in Context, Culture, Experience and Self Understanding (pp. 92-114). Cambridge: Cambridge University Press.

[12] Leech, G \& Short, M. (2007). Style in fiction: A linguistic introduction to English fictional prose. Pearson Education Ltd.

[13] Marino, S. (2005). Language and Metaphor in Arthur Miller's After the Fall. South Atlantic Review. 70(2): 41-56. Retrieved February 5, 2021, from https://www.jstor.org/stable/20064632.

[14] Miller, A. (1980). After the Fall. New York: Penguin.

[15] Moss, L. (1980). Arthur Miller. (Rev. ed.). Boston: Twayne.

[16] Nunberg, G. (1978). The pragmatics of reference. Bloomington, Indiana University Linguistics Club.

[17] Ryan, M. L. (1991). Possible worlds, artificial intelligence, and narrative theory. Indiana University Press.

[18] Stockwell, P. (2002). Cognitive poetics: An introduction. London: Routledge.

[19] Stockwell, P. (2009). Texture: a cognitive aesthetics of reading. Edinburgh University Press.

[20] Stockwell, P. (2014). How to Read a Mind: An Introduction to Understanding Literary Characters. Online Course. Retrieved February 2, 2020, from https://www.futurelearn.com/courses/how-to-read-a-mind.

[21] Wilde, O. (1891). The Picture of Dorian Gray. Simpkin, Marshall Hamilton, Kent and Co. Ltd.

Ying Fang is an associate professor at the College of International Studies, Yangzhou University, Yangzhou, Jiangsu, China. She got her Ph.D. in English language and literature from Shanghai International Studies University in 2015. She was once a visiting scholar at Huddersfield University and Sheffield Hallam University from 2014 to 2015. Her research interest mainly includes English language and literature, cognitive linguistics, stylistics, corpus linguistics, etc. Her 20 years of teaching at Yangzhou University covers linguistics, stylistics, English reading and writing, etc. She has published a number of journal papers about language and literature, and finished a provincial research project on discourse analysis. She is a member of The Poetics and Linguistics Association (PALA). 